\title{
Analisis Perputaran Modal Kerja Dalam Menilai Return On Equity Pada PT. Astra International Tbk
}

\author{
Rachmawati $^{1}$, Suparno ${ }^{2}$ \\ Sekolah Tinggi Ilmu Ekonomi Tribuana \\ wrachma654@gmail.com
}

\begin{abstract}
Abstrac
This study aims to determine working capital turnover in assessing return on equity at PT. Astra International, Tbk for the period 2015 to 2019. This study used a qualitative descriptive research method at PT. Astra International, Tbk as the object of research. Data obtained by documentation and literature techniques. Data analysis used case study (non-hypothetical). The results showed that the average working capital turnover during the 2015-2019 period was 9.21 times this turnover, this is included in the very good category and the return on equity of $14.03 \%$ is also included in the very good category based on the average standard. industry. For working capital turnover, in assessing return on equity, the research results show that working capital turnover contributes to return on equity by $64.83 \%$, this means that every 1 increase in working capital turnover contributes to return on equity by $64.83 \%$ and the rest is influenced by factors- other factors which were not examined in this study.
\end{abstract}

Keywords: Working Capital Turnover, Return On Equity

\begin{abstract}
Abstrak
Penelitian ini bertujuan untuk mengetahui perputaran modal kerja dalam menilai return on equity pada PT. Astra International, Tbk untuk periode 2015 sampai 2019. Penelitian ini menggunakan metode penelitian deskriptif kualitatif pada PT. Astra International, Tbk sebagai objek penelitian. Data diperoleh dengan teknik dokumentasi dan kepustakaan. Analisis data menggunakan studi kasus (non-hipotesis). Hasil penelitian menunjukkan bahwa rata-rata perputaran modal kerja selama periode 2015-2019 adalah 9,21 kali perputaran ini, hal ini termasuk dalam kategori sangat baik dan return on equity sebesar 14,03\% juga termasuk dalam kategori sangat baik berdasarkan standar rata-rata. . industri. Untuk perputaran modal kerja, dalam menilai return on equity, hasil penelitian menunjukkan bahwa perputaran modal kerja memberikan kontribusi terhadap return on equity sebesar $64,83 \%$, artinya setiap 1 peningkatan perputaran modal kerja memberikan kontribusi return on equity sebesar $64,83 \%$ dan sisanya dipengaruhi oleh faktor-faktor lain yang tidak diteliti dalam penelitian ini.
\end{abstract}

Kata Kunci : Perputaran Modal Kerja, Pengembalian Ekuitas

\section{PENDAHULUAN}

Pemenuhan kebutuhan manusia merupakan awal dari rangkaian proses (Marpaung, 2021b). Bagi setiap perusahaan masalah profitabilitas menjadi hal yang sangat penting. Karena bagi pimpinan perusahaan profitabilitas di gunakan sebagai tolak ukur berhasil atau tidak perusahaan yang di pimpinnya. Untuk mendapatkan profitabilitas yang tinggi perlu adanya modal kerja, karena modal kerja yang cukup memungkinkan suatu perusahaan dalam melaksanakan aktivitasnya tidak mengalami kesulitan dan hambatan yang mungkin akan timbul, dan modal kerja yang berlebihan menunjukan 
adanya dana yang tidak produktif dan memberikan kerugian karena dana yang tersedia tidak di pergunakan secara efektif dalam kegiatan perusahaan. Sebaliknya, kekurangan modal kerja merupakan sebab utama kegagalan perusahaan dalam menjalankan aktivitasnya.

Menurut Kasmir, (2012:250) modal kerja merupakan modal yang digunakan untuk melakukan kegiatan operasi perusahaan. Dengan kata lain modal kerja diartikan sebagai investasi yang ditanamkan dalam aktiva lancar atau aktiva jangka pendek, seperti : kas, bank, surat-surat berharga, piutang, persediaan, dan aktiva lancar lainnya. Modal kerja sangat berpengaruh terhadap profitabilitas karena kebijakan perusahaan dalam mengelola jumlah modal kerja secara tepat akan mengakibatkan keuntungan, sedangkan akibat dari penanaman modal kerja yang kurang tepat akan mengalami kerugian, untuk melihat efektivitas modal kerja dapat dilihat dari berapa besar modal kerja tersebut berputar dalam satu periode tertentu (Marpaung, 2021c).

Adapun perputaran modal kerja menunjukkan seberapa besar kemampuan perusahaan dalam memanfaatkan modal kerja untuk meghasilkan penjualan bersih.

Menurut Kasmir, (2010:224) perputaran modal kerja (working capital turnover) merupakan salah satu rasio untuk mengukur atau menilai keefektifannya modal kerja perusahaan selama periode tertentu. Artinya, seberapa banyak modal kerja berputar selama suatu periode atau dalam beberapa periode (Marpaung, 2021a).

Kenaikan rasio perputaran modal kerja disebabkan penjualan meningkat (lebih besar dari peningkatan modal kerja) Rasio perputaran modal kerja yang bagus adalah yang mengalami peningkatan setiap tahun, artinya perusahaan dapat memaksimalkan penjualan yang lebih tinggi, dengan tingkat penjualan yang tinggi akan menciptakan tingkap profitabilitas yang baik (Yusuf et al., 2022).

Adapun jenis-jenis rasio profitabilitas menurut Agus Sartono,(2010:113) sebagai berikut :

1. Gross Profit Margin (GPM)

2. Net Profit Margin (NPM)

3. Return On Assets (ROA)

4. Return On Equity (ROE)

Dalam penelitian ini rasio profitabilitas diukur denagan Retur On Equity (ROE) rasio ini digunakan untuk mengukur laba bersih setelah pajak dengan modal sendiri. Return On Equity yang tinggi akan dapat mendorong penerimaan perusahaan atas peluang investasi yang baik dan manajemen biaya yang efektif. Rasio ini dapat memperlihatkan seberapa banyak keuntungan yang menjadi hak pemilik modal sendiri. Return On Equity 
JURNAL PARAMETER, Volume 7 No. 1, Februari 2022 Page. 69 - 80

ISSN Cetak : 1979-8865, ISSN Online : 2716-1676

mengukur kemampuan perusahaan memperoleh laba yang tersedia bagi pemegang saham perusahaan.

$$
R O E=\frac{\text { Laba setelah Pajak }}{\text { Modal Sendiri }} \times 100 \%
$$

\section{Modal Kerja}

Setiap perusahaan membutuhkan modal kerja untuk menjalankan kegiatan operasional sehari-hari perusahaan, misalnya untuk membeli bahan baku, membayar gaji pegawai, membayar upah tenaga kerja langsung, membayar hutang dan lain sebagainya. Sejumlah dana yang telah dikeluarkan untuk membelanjai operasi perusahaan tersebut diharapkan akan dapat kembali lagi masuk dalam perusahaan dalam jangka waktu pendek melalui hasil penjualan barang maupun jasa yang dihasilkan. Uang yang masuk yang bersumber dari hasil penjualan barang tersebut akan dikeluarkan kembali guna membiayai operasi perusahaan selanjutnya untuk memperoleh laba yang diinginkan (Marpaung, 2021a).

$$
\text { Menurut Jumingan, (2011:66) }
$$

modal kerja yaitu jumlah dari aktiva lancar. Jumlah ini merupakan modal kerja bruto (gross working capital ). Definisi ini bersifat kuantitatif karena menunjukan jumlah dana yang digunakan untuk maksud-maksud operasi jangka pendek. Waktu tersedianya modal kerja akan tergantung pada macam dan tingkat likuiditas dari unsur-unsur aktiva lancar misalnya kas, surat-surat berharga, piutang dan persediaan.

Sedangkan pengertian modal kerja menurut Kasmir, (2012:250) yaitu modal yang digunakaan untuk melakukan kegiatan operasi perusahaan. Modal kerja diartikan sebagai investasi yang ditanamkan dalam aktiva lancar atau aktiva jangka pendek, seperti kas, bank, surat-surat berharga, piutang, persediaan dan aktiva lancar (Marpaung, 2022).

Manfaat Modal Kerja. Modal kerja mampu membiayai pengeluaran atau operasi perusahaan sehari-hari. Dengan modal kerja yang cukup akan membuat perusahaan beroperasi secara ekonomis dan efisien serta tidak mengalami kesulitan keuangan. Manfaat modal kerja menurut Munawir (2010: 116) adalah: 1) Melindungi perusahaan terhadap krisis modal kerja karena turunnya nilai dari aktiva lancar, 2) Memungkinkan untuk dapat membayar semua kewajibankewajiban tepat pada waktunya. 3) Memungkinkan untuk memiliki persediaan dalam jumlah yang cukup untuk melayani para konsumen (Hamid, 2021).

Memungkinkan bagi perusahaan untuk memberikan syarat kredit yang lebih menguntungkan kepada para langgananya. Memungkinkan bagi perusaahan untuk dapat beroperasi dengan lebih efesien karena tidak ada kesulitan untuk 
memperoleh barang ataupun jasa yang dibutuhkan.

Pengertian Perputaran Modal Kerja Salah satu alat ukur untuk menentukan keberhasilan manajemen modal kerja adalah diukur dari perputaran modal kerjanya atau Working Capital Turnovernya. Dengan diketahuinya modal kerja dalam suatu periode, maka akan diketahui seberapa efektif modal kerja suatu perusahaan.

\section{Menurut Kasmir,} perputaran modal kerja (working capital turnover) merupakan salah satu rasio untuk mengukur atau menilai keefektifannya modal kerja perusahaan selama periode tertentu. Artinya, seberapa banyak modal kerja berputar selama suatu periode atau dalam beberapa periode.

Untuk mengukur perputaran modal kerja adalah dengan cara membandingkan antara penjualan dengan modal kerja atau dengan modal kerja rata-rata. Penjualan yang akan dibandingkan adalah penjualan bersih (net sales) dalam suatu periode. Sedangkan pembandingnya adalah modal kerja dalam arti seluruh total aktiva lancar (current assetss) atau dapat pula digunakan modal kerja rata-rata. Pengukuran ini sebaiknya menggunakan dua periode atau lebih sebagai data pembanding, sehingga memudahkan kita untuk menilainya.

Untuk menilai keefektifan modal kerja dapat digunakan rasio antara total penjualan dengan jumlah modal kerja ratarata. Tingkat perputaran (turnover rate) modal kerja atau aktiva lancar dapat pula dihitung dari neraca dan income statement pada suatu tertentu.

Kasmir, (2012:182) merumuskan formula untuk menghitung Working Capital Turnover (WCT) adalah sebagai berikut :

Rumus :

$$
W T C=\frac{\text { Net SAles }}{\text { Current Asset-current liabilities }}
$$

Tingkat perputaran modal kerja yang tinggi mengindikasikan perusahaan telah mengelola modal kerjanya secara baik dan efisien, sebaliknya pada tingkat perputaran modal kerja yang rendah maka mengindikasikan perusahaan mengelola modal kerjanya dengan buruk. Dengan adanya perputaran modal kerja yang baik maka kegiatan operasional perusahaan pun akan berjalan dengan baik dan secara tidak langsung membawa perusahaan kedalam kondisi yang menguntungkan.

Perputaran Modal Kerja Dalam Menilai Return On Equity (ROE).

Dalam laporan keuangan modal kerja di peroleh dari jumlah aktiva lancar dikurangi hutang lancar selisih ini disebut modal kerja bersih, modal kerja digunakan oleh perusahaan dalam menjalankan kegiatan untuk satu periode tertentu dalam rangka untuk memperoleh laba melaui 
perputaran modal kerja yang dimiliki perusahaan. Oleh karena itu, semakin tinggi tingkat perputaran modal kerja berarti semakin besar kesempatan untuk memperoleh laba. Hal ini menunjukkan modal kerja perusahaan dapat terus berputar dan digunakan untuk membiayai kegiatan operasional perusahaan.

Kemampuan perusahaan untuk tetap bersaing dalam kompetisi dengan perusahaan- perusahaan lainnya, menuntut perusahaan untuk dapat meningkatkan profitabilitas. Karena semakin baik rasio profitabilitas dalam hal ini rasio return on equity maka semakin baik menggambarkan kemampuan tingginya perolehan keuntungan perusahaan. Maka semakin tinggi tingkat perputaran modal kerja akan menunjukkan tingginya volume dari penjualan perusahaan yang menggambarkan kemampuan tingginya perolehan keuntungan dalam perusahaan tersebut.

Definisi Operasional Variabel

\section{Definisi Operasional Variabel} adalah segala cara untuk mengukur konsep dan bagaimana caranya sebuah konsep harus diukur sehingga terdapat variabelvariabel yang saling mempengaruhi dan dipengaruhi, yaitu variable yang menyebabkan masalah lain dan variabel yang situasi dan kondisinya tergantung oleh variabel lain.
Dalam operasional penelitian ini, penulis menggunakan beberapa variabel penguji yang dikelompokan menjadi : Variabel Independen (X)

Variabel independen, yaitu variabel yang mempengaruhi variabel lain yang tidak bebas. Dalam hubungannya dengan judul yang ditetapkan, yang menjadi variabel independen adalah perputaran modal kerja.

Variabel Dependen (Y)

Variabel dependen, yaitu variabel yang dipengaruhi oleh variabel lainnya, maka yang menjadi variabel dependen adalah profitabilitas (Return On Equity) perusahaan.

Indikator Variabel

Indikator variabel, skala pengukuran, dan definisi yang digunakan untuk variabel independen maupun dependen dalam penelitian ini adalah sebagai berikut:

Variabel Perputaran Modal Keja

Menunjukkan hubungan antara modal kerja dengan penjulan dan menunjukkan banyaknya penjualan yang dapat diperoleh perusahaan untuk tiap rupiah modal kerja, menurut Kasmir (2012:182) indikator perputaran modal kerja yaitu.

1. Penjualan bersih

2. Modal Kerja Bersih

Variabel Profitabilitas (Return On Equity) 
Menurut Agus Sartono (2012:113) return on equity adalah menunjukkan hubungan antara laba bersih yang dihasilkan perusahaan dengan modal sendiri adapun indikator return on equity adalah :

1. Laba Bersih

2. Modal Sendiri

Hipotesis

Berdasarkan penjelasan diatas dan definisi operasional variabel maka hipotesis dalam penelitian ini adalah: "Diduga perputaran modal kerja dapat menilai return on equity"

\section{METODOLOGI PENELITIAN}

Dalam penelitian ini penulis melakukan penelitian dengan menggunakan metode deskriptif kualitatif. Menurut Nana Syaodih Sukmadinata (2011:73), penelitian deskriptif kualitatif ditunjukan untuk mendeskripsikan dan menggambarkan fenomena- fenomena yang ada, baik bersifat alamiah maupun rekayasa manusia, yang lebih memperhatikan mengenai karakteristik, kualitas, keterkaitan antar kegiatan. Selain itu penelitian deskriptif tidak memberikan perlakuan, manipulasi atau pengubahan pada variabel- variabel yang diteliti melainkan menggambarkan suatu kondisi yang apa adanya (Mardiana, 2019).

Jenis data yang digunakan dalam peneitian ini adalah data sekunder.
Menurut Sugiyono (2010:193), sumber sekunder adalah sumber yang tidak langsung memberikan data kepada pengumpul data, misalnya lewat orang lain atau dokumen.

Data yang digunakan yaitu data laporan keuangan tahunan yang dipublikasikan, yang berkaitan dengan kegiatan perusahaan selama 5 periode yaitu dari tahun 2015 - 2019, dan sumber data yang digunakan dalam peneitian ini diperoleh dari website, (http://idx.co.id/perusahaantercatat/laporan -keuangan-dan tahunan/) atau BEI (Bursa Efek Indonesia).

Teknik Analisis Data

Teknik analisis data adalah mengorganisasikan mengurutkan data kedalam pola, kategori dan satuan uraian dasar sehingga dapat ditemukan tema dan dapat dirumuskan hipotesis kerja seperti yang disarankan oleh data menurut Lexy J. Moleong, (2014:103).

Adapun metode yang dapat digunakan untuk mengelola data kualitatif adalah dengan menggunakan metode induktif.Selanjutnya yang dilakukan dalam penyusunan tahap analisis secara sistematis adalah :

1. Mengumpulkan data-data yang digunakan untuk mengukur kinerja perusahaan.

2. Menganalisis kinerja keuangan perusahaan menggunakan rasio 
profitabilitas (return on equity) yaitu sebagai berikut :

$$
R O E=\frac{\text { Laba Bersih Setelah Pajak }}{\text { Modal Sendiri }} \times 100 \%
$$

Satuan pengukuran menggunakan prosentase $(\%)$

$$
\text { Menurut Lukviarman (2017:36) }
$$
standar umum atau rata-rata industri ratioratio profitabilitas untuk retur on equity dan dapat dilihat pada tabel berikut ini :

Tabel 2.1

Standar Rasio Industri ROE

\begin{tabular}{|c|l|}
\hline Standar Industri & \multicolumn{1}{|c|}{ Kriteria } \\
\hline$\geq 8,32 \%$ & Sangat baik \\
$7,5 \%-8,31 \%$ & Baik \\
$6,5 \%-7,4 \%$ & Cukup \\
$5,5 \%-6,4 \%$ & Kurang \\
$<5,5 \%$ & Sangat Kurang \\
\hline
\end{tabular}

Menurut Lukviarman (2017:36)

Analisis Perputaran modal kerja menurut Kasmir (2016:182)

Rumus :

$$
W C T=\frac{\text { Net SAles }}{\text { Current Asset-current liabilities }}
$$

Secara umum rasio perputaran modal kerja bisa di katakan sangat baik jika mencapai standar umum rata-rata yaitu 6 kali. Di lihat dari tabel berikut ini menurut Kasmir (2016:182):
Tabel 2.2

Standar Industri Perputaran Modal Kerja

\begin{tabular}{|c|c|}
\hline Standar Industri & Kriteria \\
\hline$\geq 6$ kali & Sangat baik \\
\hline $5-6$ kali & baik \\
\hline $3-4$ kali & Cukup baik \\
\hline $1-2$ kali & Kurang baik \\
\hline$\leq 1$ kali & Buruk \\
\hline
\end{tabular}

Sumber: kasmir (2016:182)

\section{HASIL DAN PEMBAHASAN}

Perputaran Modal Kerja Pada PT. Astra International, Tbk

Perputaran modal kerja (working capital turnover) merupakan salah satu rasio untuk mengukur atau menilai keefektifannya modal kerja perusahaan selama periode tertentu. Artinya, seberapa banyak modal kerja berputar selama suatu periode atau dalam beberapa periode. Berdasarkan laporan posisi keuangan konsolidasi PT, Astra International Tbk pada periode 2015-2019 dalam milyaran rupiah, maka perputaran modal kerja adalah seperti pada tabel 3.1 berikut ini:

Tabel 3.1

\section{Perhitungan Perputaran Modal Kerja}

\begin{tabular}{|c|c|}
\hline Tahun & Perputaran Modal Kerja \\
\hline $\mathbf{2 0 1 5}$ & $6.36 \mathrm{Kali}$ \\
\hline $\mathbf{2 0 1 6}$ & $8,49 \mathrm{Kali}$ \\
\hline $\mathbf{2 0 1 7}$ & $9,12 \mathrm{Kali}$ \\
\hline $\mathbf{2 0 1 8}$ & $13,95 \mathrm{Kali}$ \\
\hline $\mathbf{2 0 1 9}$ & $8,15 \mathrm{Kali}$ \\
\hline Rata-Rata & $9,21 \mathrm{Kali}$ \\
\hline
\end{tabular}

Sumber : Lap. Keu. PT. Astra

International Tbk 
Berdasarkan tabel 4.3 diatas, dihitung dengan menggunakan rasio perputaran modal kerja pada PT. Astra International, Tbk. Tahun 2015 diperoleh hasil perputaran modal kerja sebesar 6,36 kali, di tahun 2016 perputaran modal kerja mengalami peningkatan sebesar 8,49 kali, di tahun 2017 kembali mengalami peningkatan sebesar 9,12 kali dan di tahun 2018 mengalami peningkatan yang cukup tinggi menjadi sebesar 13,95 kali. Kemudian di tahun 2019 mengalami penurunan sebesar 8,15 .

Dapat disimpulkan berdasar tabel 3.1 diats rata-rata perputaran modal kerja PT. Astra International Tbk selama periode dari tahun 2015 sampai 2019 sebesar 9,21 kali perputaran berdasrkan rata-rata industri masuk dalam katagori sangat baik karena diatas 6 kali perputaran.

Return On Equity (ROE) pada PT. Astra International, Tbk

Rasio return on equity merupakan rasio untuk menilai kemampuan perusahaan dalam mencari keuntungan. Rasio ini juga memberikan ukuran tingkat efektivitas manajemen suatu perusahaan. Tingkat return on equity yang tinggi pada perusahaan akan meningkatkan daya saing antar perusahaan dan menandakan pertumbuhan perusahaan yang baik pada masa mendatang.

Berikut ini penulis menyajikan return on equity pertahun yang terdapat pada PT. Astra Interntional, Tbk. dari tahun 2015-2019 dalam jutaan milyaran pada tabel 3.2 sebagai berikut:

Tabel 3.2

Return On Equity (ROE)

\begin{tabular}{|c|c|c|c|}
\hline Tahun & $\begin{array}{c}\text { Laba } \\
\text { Bersih }\end{array}$ & $\begin{array}{c}\text { Total } \\
\text { Aktiva }\end{array}$ & ROE \\
\hline $\mathbf{2 0 1 5}$ & 15.613 & 126.533 & $12,33 \%$ \\
\hline $\mathbf{2 0 1 6}$ & 18.302 & 139.906 & $13,08 \%$ \\
\hline $\mathbf{2 0 1 7}$ & 23.165 & 156.329 & $14,81 \%$ \\
\hline $\mathbf{2 0 1 8}$ & 27.372 & 174.363 & $15,69 \%$ \\
\hline $\mathbf{2 0 1 9}$ & 26.621 & 186.763 & $14,25 \%$ \\
& & & $\mathbf{1 4 , 0 3 \%}$ \\
\hline \multicolumn{5}{|c|}{ Rata-rata } & & Astra \\
International, Tbk. & & & \\
\hline
\end{tabular}

Dari tabel 3.2 di atas dapat dilihat bahwa return on equity (ROE) pada PT. Astra International, Tbk. dari tahun ketahun mengalami peningkatan kecuali pada tahun 2019 return on equity PT. Astra International Tbk mengalami penurunan.. Rata-rata return on equity dari tahun 2015-2019 adalah sebesar 14,03\%. Ini menunjukan kriteria sangat baik karena hasil $14,03 \%$ berada diatas $8,32 \%$ pada standar industri dengan pendekatan return on equity (ROE).

\section{Hasil Pembahasan Penelitian}

Berikut ini disajikan tabel Analisis perputaran modal kerja dalam menilai retur on asset pada PT. Astra International, Tbk dapat dilihat dari tabel 3.3 sebagai berikut: 
Tabel 3.4

Perputaran modal kerja dan Return On Equity

\begin{tabular}{|c|c|c|c|}
\hline Tahun & $\begin{array}{c}\text { Perputaran } \\
\text { modal } \\
\text { kerja }\end{array}$ & $\begin{array}{c}\text { Return } \\
\text { on Equity }\end{array}$ & $\begin{array}{c}\text { Kontribusi } \\
(\%)\end{array}$ \\
\hline $\mathbf{2 0 1 5}$ & 6,36 & 12,33 & 51,58 \\
\hline $\mathbf{2 0 1 6}$ & 8,49 & 13,08 & 64,91 \\
\hline $\mathbf{2 0 1 7}$ & 9,12 & 14,81 & 61,60 \\
\hline $\mathbf{2 0 1 8}$ & 13,95 & 15,69 & 88,89 \\
\hline $\mathbf{2 0 1 9}$ & 8,15 & 14,25 & 57,18 \\
\hline Rata & Rata & & $\mathbf{6 4 , 8 3}$ \\
\hline
\end{tabular}

Berdasarkan tabel 3.4 menunjukan bahwa pada tahun 2015 perputaran modal kerja sebesar 6,36 kali dan retur on equity sebesar 12,33\%. pada tahun 2016 perputaran modal kerja mengalami kenaikan sebesar 8,49 kali dan diikuti kenaikan retur on equity sebesar 13,08\%. Kemudian tahun 2017 perputaran modal kerja naik sebesar 9,12 hal ini terjadi dikarenakan penjualan meningkat, selanjutnya diikuti pada kenaikan retur on equity sebesar 14,81\%. lalu di tahun 2018 perputaran modal kerja mengalami kenaikan yang cukup besar yaitu sebesar 13,95 kali, diikuti dengan penurunan pada retur on equity sebesar $15,69 \%$. dan di tahun berikutnya 2019 perputaran modal kerja mengalami penurunan sebesar 8,15 kali, dan diikuti oleh penurunan retur on equity menjadi sebesar $14,25 \%$ yang disebabkan karena meningkatnya jumlah modal sendiri. Dari penjelasan diatas dapat disimpulkan bahwa perubahan perputaran modal kerja linier dengan perubahan retur on equity (ROE)

$$
\text { Berdasarkan table } \quad 3.4
$$

perbandingan perputaran modal kerja dan retur on equity di atas setiap 1 kali perputaran modal kerja memberi kontrobusi sebesar $51,58 \%$ pada retur on equity di tahun 2015. Di tahun 2016 setiap 1 kali perputaran modal kerja akan memberi kontribusi $64,91 \%$ pada retur on equity. kemudian di tahun 2017 setiap 1 kali perputaran modal kerja memberi kontribusi sebesar $61,60 \%$ pada retur on equity. Lalu, di tahun 2018 setiap 1 kali perputaran modal kerja akan memberi kontribusi sebesar $88,89 \%$ pada retur on equity di tahun 2019 setiap 1 kali perputaran modal kerja akan memberi kontribusi sebesar $57,18 \%$ pada retur on equity.

Kemudian dari analisis perbandingan perputaran modal kerja dan retur on equity selama 5 tahun terakhir yaitu periode tahun 2015 sampai dengan tahun 2019 diperoleh rata-rata sebesar 9,21 kali perputaran modal kerja dan diikuti retur on equity sebesar $14,03 \%$ rata-rata pertahun. Hal ini menunjukan bahwa ada kontribusi antara perputaran modal kerja dengan return on equity sebesar $64,83 \%$ dan sisanya berkontribusi pada faktor lain yang tidak diteliti dalam penelitian ini. 
Pendapat Penulis

Dari hasil analisis penulis didapatkan hasil perputaran modal kerja pada periode dari tahun 2015 sampai dengan 2019 PT. Astra International, Tbk rata-rata sebesar 9,21 kali perputaran ini masuk dalam katagori sangat baik karena diatas 6 kali perputaran, berdasarkan standar rata-rata industri, sedangkan retur on equity nilai rata-rata sebesar $14,03 \%$ masuk katagori sangat baik karena berada diatas 8,32 rata-rata industri.

Analisis perbandingan perputaran modal kerja dan retur on equity selama lima tahun terakhir, bahwa ada kontribusi antara perputaran modal kerja dengan return on equity rata-rata sebesar $64,83 \%$ dan sisanya berkontribusi pada faktor lain yang tidak diteliti dalam penelitian ini.

Dari hasil penelitian penulis dapat dijelaskan bahwa perputaran modal kerja dapat menilai return on equityt. (ROE) Temuan hasil penelitian ini mendukung pendapat atau teori lama yang menyatakan bahwa perputaran modal kerja dapat menilai return on equity hal ini didasarkan pada teori dari Kasmir.

\section{KESIMPULAN}

Dari hasil penelitian dan pembahasan analisis perputaran modal kerja dalam menilai return on equity, PT. Astra International Tbk. Selama 5 periode terakhir yaitu tahun 2015-2019. Maka dapat ditarik kesimpulan sebagai berikut :

1. Besarnya perputaran modal kerja PT. Astra International, Tbk cenderung mengalami kenaikan dan penurunan. hanya terjadi pada tahun 2019 ini disebabkan adanya penurunan hutang lancar, sedangkan penjualan meningkat. Untuk rata-rata perputaran modal kerja PT. Astra International Tbk dalam periode 2015 - 2019 yaitu sebesar 9,21 Kali perputaran hal ini masuk dalam katagori sangat baik berdasarkan standar rata rata industri.

2. Return on equity, PT. Astra International, Tbk selama 5 periode yaitu tahun 2015-2019 cenderung mengalami peningkatan kecuali tahun 2019 return on equity mengalami penurunan, hal ini berkurangnya laba bersih dan terjadi peningkatan pada modal sendiri pada periode tersebut, sedangkan rata-rata retur on equity PT. Astra International Tbk selama periode tahun 2015-2019 adalah sebesar 14,03 hal ini masuk dalam katagori sangat baik menurut standar rata-rata industri.

3. Berdasarkan hasil pengujian analisis perputaran modal kerja dan return on equity PT. Astra International Tbk, bahwa perputaran modal kerja dapat memberikan kontribusi sebesar rata-rata sebesar $64,83 \%$ artinya setiap 1 kali perputaran modal kerja dapat 
memberikan kontribusi kepada retur on equity (ROE) sebesar 64,83\% dan sisanya dipengaruhi oleh faktor-faktor lain yang tidak diteliti pada penelituian ini.

\section{REFERENSI}

Agus Sartono, (2010). Manajemen Keuangan Teori dan Aplikasi. Edisi ketiga. BPFE Yogyakarta

(2012). Manjamen Keuangan Teori dan Aplikasi, Edisi Keempat. Yogyakarta : BPFE.

(2013). Manjamen Keuangan Teori dan Aplikasi, Edisi Kelima. Yogyakarta : BPFE

Brealey, et. Al. (2012). Dasar-dasar Manajemen Keuangan, Jakarta : Penerbit Erangga

Fahmi, Irham. (2012). Analisis Laporan Keuangan, Bandung : Alfabeta.

Gunawan, (2014). Metodologi Penelitian Untuk Bisnis, Edisi 4. Jakarta : Salemba Empat

Indrawan dan Poppy, (2014). Metode Penelitian Kualitatif. Jakarta : Kencana Predana Media

Jumingan. (2011). Analisis Laporan Keuangan, Jakarta : Bumi Aksara

Hamid, E. (2021). Analisis Perputaran Persediaan Dalam Menilai Return On Asset (ROA) Pada PT. Kalbe Farma, Tbk Periode 2015 - 2019. Parameter, $6(1), 1-11$.

https://doi.org/10.37751/parameter.v6 i1.157

Mardiana, N. R. (2019). Analisa Pengaruh Brand Ambassador, Citra Merek Dan Kualitas Produk Terhadap Minat Beli Produk Kosmetik Emina. ISSN 25023632 (Online) ISSN 2356-0304 (Paper) Jurnal Online Internasional
\& Nasional Vol. 7 No.1, JanuariJuni 2019 Universitas 17 Agustus 1945 Jakarta, 53(9), 1689-1699. www.journal.uta45jakarta.ac.id Marpaung, N. N. (2021a). Implementation of Online Learning Applications in SD Bina Kreasi Mandiri Bekasi : Infrastructure Effect Analysis. 2019(December 2019), 1796-1807.

Marpaung, N. N. (2021b). Relationship of Brand Ambassadors with Interest to Buy : Lazada e-Commerce Study. 7(2), 341-352.

Marpaung, N. N. (2021c). ANALISIS

PERPUTARAN KAS DALAM

MENILAI RETURN ON ASSET

PADA PT. PRASIDHA ANEKA

NIAGA, Tbk. PARAMETER, 4(2). https://doi.org/10.37751/parameter.v4 i2. 155

Marpaung, N. N. (2022). Dinamika Kinerja Karyawan PT Adia Mirsi Mindo ( AMM ) Jakarta ; Analisis Pengaruh Motivasi Kerja. 7(1).

Yusuf, M., Teknologi, I., \& Rakyat, B. (2022). EFEECT OF SHARIA COMPLAINCE, GOVERNANCE, AND SOCISL RESPONSIBILITY ON BUSINESS SUSTAINABILITY : MEDIATING ROLE OF BUSNIESS GROWTH. 28(1), 2686.

Kasmir. (2010). Analisis Laporan Keuangan, Jakarta : Rajawali Pers (2011). Analisis Laporan Keuangan, Jakarta : PT. Raja Grafindo Persada.

(2014). Analisis Laporan Keuangan, Edisi Pertama. Cetakan Ketujuh. Jakarta : Rajagrafindo Persada. (2016). Analisis Laporan Keuangan, Jakarta : Raja Grafindo Persada.

Lukviarman, Niki. (2017). Corporate Govermance, Solo: PT. Era Adicitra Intermedia.

Lexy J. Moleong (2014) Metodologi Penelitian Kualitatif PT Remaja Rosdakarya Offset-Bandung 
JURNAL PARAMETER, Volume 7 No. 1, Februari 2022 Page. 69 - 80

ISSN Cetak : 1979-8865, ISSN Online : 2716-1676

Munawir. (2010). Analisis Laporan

Keuangan. Edisi Keempat. Cetakan

Kelima Belas, Yogyakarta : Liberty

Riyanto, Bambang. (2010). Dasar-dasar

Pembelanjaan Perusahaan,

Yogyakarta : BPFE UGM

(2012). Dasar - dasar Pembelanjaan

Perusahaan, Edisi Kedua

Yogyakarta : BPFE UGM

Sawir. (2014). Analisis Kinerja Keuangan

dan Perencanaan Keuangan

Perusahaan. Jakarta : Gramedia

Pustaka Utama

Sukmadinata, Nana Syaodih. (2011).

Metode Penelitian Pendidikan,

Bandung : PT Remaja Rosdakarya

Sugiyono, (2010). Statistik Untuk

Penelitian, Bandung : Alfabeta

(2011). Metode Penelitian

Kombinasi, Bandung : Alfabeta.

(2012). Metode Penelitian

Kuantitatif Kualitatif R\&D,

Bandung : Alfabeta.

(2014). Metode Penelitian Kuantitatif

dan Kualitatif, Bandung : Alfabeta

Bursa Efek Indonesia, melalui URL : http://www.idx.co.id

http://adaddanuarta.blogspot.com/2014/11/ perputaran-modal-kerja-menurutpara-ahli.html 